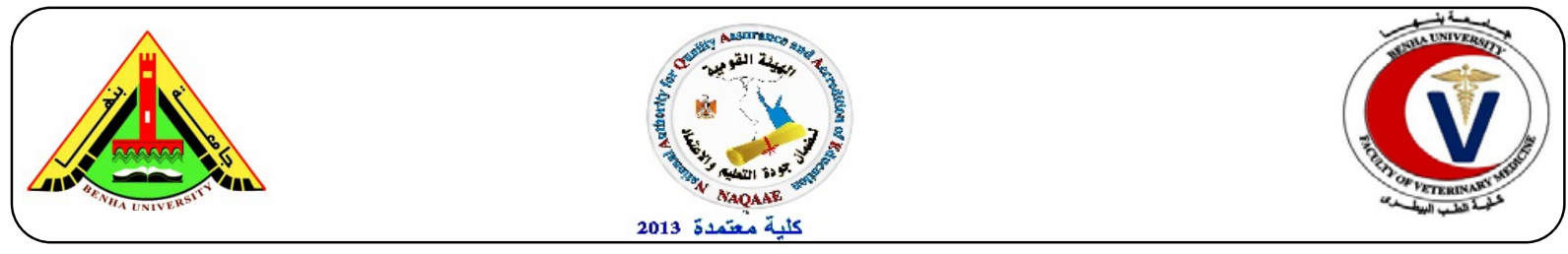

\title{
Antibacterial Action of Zinc Oxide Nanoparticles against Staphylococcus aureus in Broiler Breast Fillet
}

\author{
Hemmat, M., Ibrahim¹; Reham, A., Amin ${ }^{1}$; Nesreen, Z., Eleiwa ${ }^{2}$ and Heba, G., Rezk ${ }^{3}$ \\ ${ }^{1}$ Food Control Department, Faculty of Veterinary Medicine, Benha University, Egypt \\ ${ }^{2}$ Food Hygiene Department, Animal Health Research Institute, Tanta Lab., Egypt \\ ${ }^{3}$ Food Hygiene Specialist, Tanta University, Egypt
}

\section{A B S T R A C T}

Zinc oxide can be called a multifunctional material thanks to its unique physical and chemical properties. Practical application of zinc oxide nanoparticles ( $\mathrm{ZnO} \mathrm{NPs}$ ) suspension with different concentrations $(5,8$, and $10 \mathrm{mM})$ were investigated against Staphylococcus aureus artificially inoculated into broiler breast fillets. The results indicated that $\mathrm{ZnO}$ suspensions $(5,8$ and $10 \mathrm{mM}$ ) had a significant inhibitory effect on the growth of Staphylococcus aureus during 12 days of refrigerator storage at $4^{\circ} \mathrm{C}$. Accurately, $\mathrm{ZnO}$ NPs $10 \mathrm{mM}$ showed the highest reduction percentage $(25.35 \%)$ to Staphylococcus aureus from 8.6 to $6.42 \mathrm{log} \mathrm{cfu} / \mathrm{g}$, compared to other concentrations ( 5 and $8 \mathrm{mM}$ ). Thus, that the antibacterial activity of $\mathrm{ZnO}$ was concentration dependent.

Key words: $\mathrm{ZnO}$ nanoparticles - broiler breast fillets -Antibacterial Activity-Staphylococcus aureus.

\section{INTRODUCTION}

Poultry meat has become a mass consumer product throughout the world. Poultry is a food that has been highly appreciated by man since time immemorial. It is an important, low cost source of animal protein, rich in nutrients, phosphorous, other minerals and B-complex vitamins (FAO, 2010). Food borne illness in human beings due to bacterial pathogens and their toxins are well known all over the world (Hazairwala et al., 2002). Food borne illness leads to a substantial economic and quality of life by a way of acute morbidity and chronic sequels (Duff et al., 2003). In this respect, nanotechnology represents the vanguard of the wave of innovations that is perhaps going to shake the agro-food sector in the years ahead. The advent of nanotechnology which involves the manufacture and use of materials with size of up to about $100 \mathrm{~nm}$ in one or more dimensions has brought great opportunities for the development of materials with new properties for use as antimicrobial agents (Roco, 1999). These novel and enhanced material properties are the results of the increase in relative surface area that occurs as particle size decreases down to the nano-scale. Nanosize materials are also more biologically active compared to the same material in the macro or micro scale (Ren et al., 2009). Nanosized inorganic compounds display strong antibacterial activity at low concentrations and unique chemical and physical properties (Rai et al., 2009). A key advantage of inorganic nanoparticles in their stability under extreme conditions, such as high temperatures and pressures. (Sawai 2003). Also some inorganic nanoparticles are considered nontoxic because they contain minerals essential to the human body (Roselli et al., 2003). Most antibacterial inorganic materials are metallic nanoparticles and metal oxide nanoparticles such as silver, copper, titanium oxide, and zinc oxide (ZnO) (Bradley et al., 2011). In general, Zinc oxide $(\mathrm{ZnO})$ is one of the five zinc compounds that are currently listed as GRAS by the FDA (FDA, 2011). ZnO powder has been used for decades as an active ingredient for dermatological applications in creams, lotions, and ointments because of its antibacterial properties (Sawai, 2003). Futher, ZnO NPs as nontoxic and biocompatible, have been utilized in many biological applications in daily life such as drug carriers, cosmetics and medical devices. However, these NPs have not been applied in fresh meat. The present work was carried out to evaluate the efficacy of $\mathrm{ZnO}$ NPs $(20 \mathrm{~nm})$ as antimicrobial agents on the survival of Staphylococcus aureus 
artificially inoculated into broiler breast fillet (in vivo).

\section{MATERIALS AND METHODS}

\subsection{Preparation of Bacterial strain:}

The tested Staphylococcus aureus was biochemically identified by Animal Health Research Institute, Egypt The bacterial strain was maintained in tryptic soy agar (Merck, Germany). Four to five isolated colonies of the tested strain were picked up and inoculated in tubes of sterile peptone water $0.1 \%$ (Merck, Germany) $(5 \mathrm{ml}$ in each) then incubated at $37^{\circ} \mathrm{C} / 24 \mathrm{hrs}$ (Saeed and Tariq, 2005). From this culture, dilutions up to $10^{10}$ were plated on Baired Parker agar (Merck, Germany) to determine the cell concentration. The cell count was adjusted to $10^{7} \mathrm{cfu} / \mathrm{ml}(7 \log \mathrm{cfu} / \mathrm{ml})$ for Staph. aureus (Kantachote and Charernjiratrakul, 2008) (the infective dose of enterotoxin may be achieved when the population of Staph. aureus reaches a level of $>10^{5} \mathrm{cfu} / \mathrm{g}$ ) (Stewart et al., 2003) with tube dilution methods. The number of $\mathrm{cfu} / \mathrm{ml}$ was considered as initial inoculum load to be inoculated into broiler breast fillet samples.

\subsection{Preparation of zinc oxide nanoparticles:}

$\mathrm{ZnO}$ nanoparticles with (diameter, $20 \mathrm{~nm}$; purity, 99.98\%) were purchased from NanoTech Egypt for Photo-Elecronics according to NTZONP brand with certificate of analysis. To obtain a homogenous solution of nanoparticles at different concentrations, including concentrations $(5 \mathrm{Mm}$, $8 \mathrm{mM}$ and $10 \mathrm{mM}$ ), $150 \mathrm{ml}$ distilled water were added to each concentration of nanoparticles in glass containers and sonicated for $30 \mathrm{~min}$. for uniform dispersion and formed a colloidal suspension. Then, the resulting homogenous suspensions were autoclaved for 30 minutes to be sterilized (Mottaki et al., 2014).

\subsection{Broiler breast fillet samples:}

A total of 1200 grams of random samples of fresh raw broiler fillets were purchased from different shops and supermarkets at El-Gharbia province. The samples will keep in separate plastic bags and transferred directly to the laboratory in an insulated ice box under complete aseptic conditions without undue delay. In the laboratory, all samples were divided into 4 equal groups, (each group was 100 grams) washed with sterile distilled water and stored at $4^{\circ} \mathrm{C}$ until use.

\subsection{Artificial inoculation of broiler breast fillet samples with staphylococcus aureus:}

Broiler breast fillet samples were dipped in 150 $\mathrm{ml}$ of sterile pepton water $0.1 \%$ (Merk, Germany) containing Staph. aureus at approximately $7 \log$ $\mathrm{cfu} / \mathrm{ml}$ for $15 \mathrm{~min}$. at room temperature $\left(25^{\circ} \mathrm{C}\right)$. After dipping, the fillet samples were kept at room temperature for $20 \mathrm{~min}$. to allow attachment and absorption of bacteria (Dubal et al., 2004). Then, Staphylococcus aureus in the samples was enumerated to get the initial load before dipping in $\mathrm{ZnO}$ nanoparticles suspensions.

\subsection{Application of zinc oxide nanoparticles:}

Broiler breast fillet samples with known load of the tested organism (staph.aureus) were dipped in sterile distilled water (control), $5 \mathrm{mM} \mathrm{ZnO} \mathrm{NP}$ suspension, $8 \mathrm{mM} \mathrm{ZnO}$ NP suspension and $10 \mathrm{mM}$ $\mathrm{ZnO} \mathrm{NP}$ suspension at room temperature $\left(25^{\circ} \mathrm{c}\right)$ for 15 min. All groups were properly packed in polyethylene bags, labeled and stored at $4^{\circ} \mathrm{C}$. Sensory analysis (overall acceptability) and Staph.aureus count analysis were conducted on days $0,3,6,9$ during storage, using the serial dilutions and spread plate technique (FDA, 2001). The above experiment was performed in triplicate.

\subsection{Sensory examination:}

Overall acceptability of all samples was carried out using a 10 - point standardized numerical scale, where 10 corresponded to 'components characteristic of the highest quality'. The panel consisted of 10 members of the staff who were familiar with meat characteristics was conducted during storage according to Kanatt et al., (2010).

\subsection{Bacteriological analysis:}

Staphylococcus aureus count was applied using standard methods (FDA, 2001). Thereafter, black shiny colonies with narrow white margins surrounded by a clear halo zone extending into the opaque Baired parker medium were counted and expressed as colony forming units (log $\mathrm{cfu} / \mathrm{g})$. The mean of log cfu/g calculated from two replications of each sampling point were expressed as bacterial survival counts.

\subsection{Statistical analysis:}

All the obtained data were statistically analyzed by one-way analysis of variance (ANOVA) using SPSS package (SPSS 19.0, Chicago, IL, USA). Significant $(P<0.05)$ differences between treatments were determined using Duncan's post hoc test. Data were expressed as means \pm standard deviation (SD).

\section{RESULTS}




\subsection{Sensory examination:}

The results obtained in table (1) showed that the mean values of overall acceptability in case of using $\mathrm{ZnO}$ NPs $(5 \mathrm{mM})$ were $6.33 \pm 0.5,8.00 \pm 1.00$, $7.00 \pm 1.00,4.67 \pm 0.58(\log \mathrm{cfu} / \mathrm{g})$ at zero day, $3^{\text {rd }}$ day, $6^{\text {th }}$ day and $9^{\text {th }}$ day of the refrigerated storage period at $4{ }^{\circ} \mathrm{C}$, respectively. While in case of using $\mathrm{ZnO}$ NPs $(10 \mathrm{mM})$ the mean values were $6.67 \pm$ $0.58,7.67 \pm 0.58,6.67 \pm 0.58,7.00 \pm 1.00,6.67 \pm$ $0.58(\log \mathrm{cfu} / \mathrm{g})$ at zero day, $3^{\text {rd }}$ day, $6^{\text {th }}$ day, $9^{\text {th }}$ day and $12^{\text {th }}$ day of the storage period at $4{ }^{\circ} \mathrm{C}$ respectively. In case of using $\mathrm{ZnO}$ NPs $(8 \mathrm{mM})$ the mean values were $8.33 \pm 0.58,8.33 \pm 0.58,7.00 \pm$ $1.00,7.67 \pm 0.58,7.00 \pm 0.00(\log \mathrm{cfu} / \mathrm{g})$ at zero day, $3^{\text {rd }}$ day, $6^{\text {th }}$ day, $9^{\text {th }}$ day and $12^{\text {th }}$ day of the refrigerated storage period at $4{ }^{\circ} \mathrm{C}$, respectively. Comparing with the mean value of overall acceptability in the control samples which was 8.00 $\pm 1.00(\log \mathrm{cfu} / \mathrm{g})$ at zero day then the samples showed extreme discoloration and off-odor on the third day of storage indicating complete spoilage.

\subsection{Bacteriological examination:}

Table (2) revealed Staph.aureus counts (log $\mathrm{cfu} / \mathrm{g}$ ) artificially inoculated into raw broiler breast fillet samples during refrigerated storage with different concentrations of $\mathrm{ZnO}$ NPs $(20 \mathrm{~nm})$. The present data exhibited the potential of $\mathrm{ZnO}$ NPs as food preservative against Staph.aureus in broiler breast fillet samples. The initial counts of Staph.aureus in broiler breast fillet samples after inoculation were $8.60 \pm 1.07 \log \mathrm{cfu} / \mathrm{g}$. At zero day counts of Staph.aureus in broiler breast fillet samples were $8.38 \pm 1.24 ; 8.16 \pm 1.04$ and $8.01 \pm$
$0.23 \log \mathrm{cfu} / \mathrm{g}$, after treatment with $\mathrm{ZnO}$ NPs $5 \mathrm{mM}$, $8 \mathrm{mM}, 10 \mathrm{mM} \mathrm{ZnO}$ NPs respectively, Comparing with Staph. aureus count in the control $(\mathrm{P}<0.05)$ which was $8.52 \pm 1.20 \log \mathrm{cfu} / \mathrm{g}$. By $3^{\text {rd }}$ day of refrigerated storage period such count of Staph.aureus slightly decreased to $7.75 \pm 0.17$; $7.75 \pm 0.74$ and $7.49 \pm 0.76 \log \mathrm{cfu} / \mathrm{g}$ after treatment with $\mathrm{ZnO}$ NPs $5 \mathrm{mM}, 8 \mathrm{mM}, 10 \mathrm{mM} \mathrm{ZnO}$ NPs, respectively, as well as they were acceptable from aesthetic points without off odor or discoloration compared with the control +ve. Samples which showed extreme discoloration and off-odor on the $3^{\text {rd }}$ day of refrigerated storage indicating complete spoilage. While, the $6^{\text {th }}$ day of refrigerated storage of treated samples with ZnO NPs 5mM, 8mM, 10 $\mathrm{mM} \mathrm{ZnO}$ NPs, the mean counts of Staph.aureus were $7.52 \pm 0.65 ; 7.35 \pm 0.68$ and $7.25 \pm 0.62$, respectively, as well as they were still acceptable without off odor or discoloration. By $9^{\text {th }}$ day of refrigerated storage, count of Staph.aureus decreased to $7.32 \pm 0.77 ; 6.65 \pm 0.60$ and $6.42 \pm$ $0.54 \log \mathrm{cfu} / \mathrm{g}$, after treatment with $\mathrm{ZnO}$ NPs $5 \mathrm{mM}$, $8 \mathrm{mM}, \quad 10 \mathrm{mM} \mathrm{ZnO} \mathrm{NPs}$, respectively. As illustrated in table (3) ZnO NPs 5mM reduced the growth of Staph.aureus $2.56 \% ; 9.88 \% ; 12.56 \%$ and $14.88 \%$ after zero day, $3^{\text {rd }}$ day, $6^{\text {th }}$ day and $9^{\text {th }}$ day of refrigerated storage, respectively. At the concentration of $\mathrm{ZnO}$ NPs $8 \mathrm{mM}$ reduced the growth of Staph.aureus 5.12\%; 11.98\%; 14.53 and $22.67 \%$ after zero day, $3^{\text {rd }}$ day, $6^{\text {th }}$ day and $9^{\text {th }}$ day of refrigerated storage, respectively. Moreover $\mathrm{ZnO}$ NPs $10 \mathrm{mM}$ reduced the growth of Staph.aureus $6.86 \% ; 12.91 \% ; 15.70 \%$ and $25.35 \%$ after zero day, $3^{\text {rd }}$ day, $6^{\text {th }}$ day and $9^{\text {th }}$ day of refrigerated storage, respectively.

Table (1): Effect of $\mathrm{ZnO} \mathrm{NP}(20 \mathrm{~nm})$ on overall acceptability of raw broiler breast fillet samples during refrigeration storage $(n=30)$

\begin{tabular}{lccccc}
\hline Groups & Zero day & $3^{\text {rd }}$ day & $6^{\text {th }}$ day & $9^{\text {th }}$ day & $12^{\text {th }}$ day \\
\hline & & & & & \\
Control & $8.00 \pm 1.00^{\mathrm{ab}}$ & Spoiled & Spoiled & Spoiled & Spoiled \\
$5 \mathrm{mM} \mathrm{ZnO} \mathrm{NP}$ & $6.33 \pm 0.5^{\mathrm{b}}$ & $8.00 \pm 1.00^{\mathrm{a}}$ & $7.00 \pm 1.00^{\mathrm{a}}$ & $4.67 \pm 0.58^{\mathrm{b}}$ & Spoiled \\
$(20 \mathrm{~nm})$ & & & & \\
$8 \mathrm{mM} \mathrm{ZnO} \mathrm{NP}$ & $8.33 \pm 0.58^{\mathrm{a}}$ & $8.33 \pm 0.58^{\mathrm{a}}$ & $7.00 \pm 1.00^{\mathrm{a}}$ & $7.67 \pm 0.58^{\mathrm{a}}$ & $7.00 \pm 0.00$ \\
$(20 \mathrm{~nm})$ & & & & & \\
$10 \mathrm{mM} \mathrm{ZnO} \mathrm{NP}(20 \mathrm{~nm})$ & $6.67 \pm 0.58^{\mathrm{ab}}$ & $7.67 \pm 0.58^{\mathrm{ab}}$ & $6.67 \pm 0.58^{\mathrm{a}}$ & $7.00 \pm 1.00^{\mathrm{a}}$ & $6.67 \pm 0.58$ \\
\hline
\end{tabular}

The values represent Mean \pm SD of three experiments. Means within a column followed by different letters are significantly different $(P<0.05)$. Score System for Sensory Evaluation (Kanatt et al., 2010):

9: Excellent

8: Very very good

7: Very good
6: Good 3: Poor

5: Medium 2: Very poor

4: Fair

1: Very very poor 
Table (2): Effect of different concentrations of $\mathrm{ZnO} N \mathrm{NP}(20 \mathrm{~nm})$ on Staphylococcus aureus count (log cfu/g) artificially inoculated into raw broiler breast fillet samples during refrigeration storage $(n=30)$

\begin{tabular}{ccccc}
\hline Groups & Zero day & $3^{\text {rd }}$ day & $6^{\text {th }}$ day & $9^{\text {th }}$ day \\
\hline Control & & & & \\
$5 \mathrm{mM} \mathrm{ZnO}(20 \mathrm{~nm})$ & $8.52 \pm 1.20^{\mathrm{a}}$ & ---- & --- & \\
$8 \mathrm{mM} \mathrm{ZnO}(20 \mathrm{~nm})$ & $8.16 \pm 1.04^{\mathrm{a}}$ & $7.75 \pm 0.17^{\mathrm{a}}$ & $7.52 \pm 0.65^{\mathrm{a}}$ & $7.32 \pm 0.77^{\mathrm{a}}$ \\
$10 \mathrm{mM} \mathrm{ZnO}(20 \mathrm{~nm})$ & $8.01 \pm 0.23^{\mathrm{a}}$ & $7.49 \pm 0.74^{\mathrm{a}}$ & $7.35 \pm 0.68^{\mathrm{a}}$ & $6.65 \pm 0.60^{\mathrm{a}}$ \\
\hline
\end{tabular}

(----): Organoleptically spoiled samples. Initial load of Staph. aureus $=8.60 \pm 1.07 \mathrm{log} \mathrm{cfu} / \mathrm{g}$. The values represent Mean \pm SD of three experiments. Means within a column followed by same letters are non-significant $(P<0.05)$.

Table (3): Reduction \% of Staphylococcus aureus count (log cfu/g) artificially inoculated into raw broiler breast fillet samples treated with different concentrations of ZnO NP $(20 \mathrm{~nm})$

\begin{tabular}{lccccccccc}
\hline Groups & \multicolumn{2}{c}{ Zero day } & \multicolumn{2}{c}{$3^{\text {rd }}$ day } & \multicolumn{3}{c}{$6^{\text {th }}$ day } & \multicolumn{2}{c}{$9^{\text {th }}$ day } \\
& $\log$ & $\%$ & $\log$ & $\%$ & $\log$ & $\%$ & $\log$ & $\%$ \\
\hline $\begin{array}{l}\text { Control } \\
5 \mathrm{mM} \mathrm{ZnO}\end{array}$ & 0.08 & 0.93 & & --- & & --- & & -- \\
$(20 \mathrm{~nm})$ & 0.22 & 2.56 & 0.85 & 9.88 & 1.08 & 12.56 & 1.28 & 14.88 \\
$\begin{array}{l}8 \mathrm{mM} \mathrm{ZnO} \\
(20 \mathrm{~nm})\end{array}$ & 0.44 & 5.12 & 1.03 & 11.98 & 1.25 & 14.53 & 1.95 & 22.67 \\
$\begin{array}{l}10 \mathrm{mM} Z n O \\
(20 \mathrm{~nm})\end{array}$ & 0.59 & 6.86 & 1.11 & 12.91 & 1.35 & 15.70 & 2.18 & 25.35 \\
\hline
\end{tabular}

\section{DISCUSSION}

Depending on the concentration, $\mathrm{ZnO}$ NPs could significantly reduce Staph.aureus count in broiler breast fillet samples. Our result is similar to those reported by (Etman, 2015; El-Fiky, 2014) who studied the effect of ZnO NPs on $L$. monocytogenes in ready to eat meat products and fresh minced meat, respectively. Finally, (Mirhosseini and Arjmand, 2014) proved the activity of $\mathrm{ZnO}$ NPs with acetic acid on Staph. aureus in mutton meat.

The exact antibacterial mechanism of $\mathrm{ZnO}$ nanoparticles is still unknown. However, many antibacterial mechanisms of $\mathrm{ZnO}$ nanoparticles such as the formation of reactive oxygen species (ROS), the interaction of nanoparticles with bacteria, subsequently damaging the bacterial cell, and the release of $\mathrm{Zn}^{2}+$ have been proposed (Manna, 2012). Many studies have indicated that the formation of ROS is the main antibacterial mechanism of $\mathrm{ZnO}$ nanoparticles (Zhang et al., 2008; Espitia et al., 2012). The antibacterial effect of $\mathrm{ZnO}$ can also be the result of mechanical damage to the cell membrane caused by the abrasive surface of nanoparticles, since ZnO NPs have been considered to be abrasive due to surface defects such as edges and corners (Stoimenov et al., 2002). The orientation of $\mathrm{ZnO}$ which affects the biocidal activity of $\mathrm{ZnO}$ because of its various randomly oriented spatial configurations, which exhibits higher antibacterial action compared with those of regularly arranged structures (Ramani et al., 2014).

Particle size and concentration of $\mathrm{ZnO}-\mathrm{NPs}$ play important roles in the antibacterial activity. ZnO-NPs antibacterial activity directly correlates with their concentration as reported by several studies, the activity is size dependent, however, this dependency is also influenced by concentration of NPs (Sirelkhatim et al., 2015). Larger surface area and higher concentration are accountable for $\mathrm{ZnO}$ NPs antibacterial activity (Peng et al., 2011). ZnO NPs of smaller sizes can easily penetrate into bacterial membranes due to their large interfacial area, thus enhancing their antibacterial efficiency. Studies investigated on the impact of particle size on the antibacterial activity, and authors found that controlling ZnO NPs size was crucial to achieve best bactericidal response, and $\mathrm{ZnO}$ NPs with smaller size (higher specific surface areas) showed highest antibacterial activity (Zhang et al., 2007). The dissolution of ZnO NPs into $\mathrm{Zn}^{2}+$ was reported as size dependent. Moreover, the generation of $\mathrm{H}_{2} \mathrm{O}_{2}$, affected by size and concentration of NPs. The smaller particle gives larger surface area so, greater antibacterial activity. (Padmavathy and Vijayaraghavan, 2008). So, inhibition of bacterial growth is completely 
related to the concentrations of $\mathrm{ZnO}$ NPs and the initial number of bacterial cells. As a matter of fact, antibacterial activity of $\mathrm{ZnO}$ NPs is a dosedependent issue.

\section{CONCLOSION}

The noble properties and attractive characteristics of $\mathrm{ZnO} \mathrm{NPs}$ confer significant toxicity to organisms which have made ZnO NPs successful candidate among other metal oxides. The antibacterial activity of $\mathrm{ZnO}$ nanoparticles is size and concentration dependent. It is still not clear whether ZnO NPs are safe for human health. Results to date show that $\mathrm{ZnO}$ NPs are safe up to a certain level, but may become toxic at higher concentrations. In future, more research should be focused on the safety evaluation and antimicrobial activity of $\mathrm{ZnO}$ NPs in vivo need to be undertaken.

\section{REFERENCES}

Bradley, E.L., Castle, L. and Chaudhry Q (2011): Applications of nanomaterials in food packaging with a consideration of opportunities for developing countries. Trends in Food Science \& Technology, In Press, Accepted Manuscript, doi: 10.1016/j.tifs.01.002.

Duff, S.B., E.A. Scott, M.S. Mafilios, E.C. Todd, L.R. Krilo, A.M. Gedded and S.J. Ackerman. (2003): Cost effectiveness of a targeted disinfection program in household kitchens to prevent food-borne illnesses in the United States, Canada and the United Kingdom. Journal of food Ptection bb (II): 2103-2115.

Dubal, Z.B.; Paturkar, A.M.; Waskar, V.S.; Zende, R.J. and Latha, C. et al. (2004): Effect of food grade organic acids on inoculated $\mathrm{S}$. aureus, L.monocytogenes, E. coli and S.typhimurium in sheep/goat meat stored at refrigeration temperature. J. Meat Sci., 66: 817-821.

El-Fiky, S. El- Saeed. (2014): Effect of zinc oxide nanoparticles on listeria monocytogenes in meat product. M.V.Sc. Thesis (Meat Hygiene). Fac. Vet. Med., Damanhour University Egypt.

Espitia, P.J.P.; Soares, N.F.F.; Coimbra, J.S.R.; Andrade, N.J.; Cruz, R.S.; Medreiros, E.A.A. (2012): Zinc oxide nanoparticles: synthesis, antimicrobial activity and food packaging applications. Food Bioprocess Technol., 5:1447-1464.
Etman, M.M. (2015): Effect of zinc oxide nanoparticles on Listeria monocytogenes in ready to eat meat. M.V.Sc. Thesis (Meat Hygiene). Fac. Vet. Med., Damanhour University.

FAO (2010): Poultry Meat \& Eggs. Investment Center Division. Vialedelle Terme di Caracalla, 00153 Rome, Italy.

FDA "Food and Drug Administration" (2001): Evaluation and definition of potentially hazardous foods. Analysis of microbial hazards related to time / temperature control of food for safety. Department of Health and Human Services. Food and Drug Administration Chapter 4:1-19.

FDA "Food and Drug Administration" (2011): Part 182 - substances generally recognized as safe. Food and drug administration, Washington DC, USA. Available at: http://ecfr.gpoaccess.gov/cgi/t/text/text-idx.

Hazariwala, A., Q. Sanders, C.R. Hudson, C. Hofacre, S.G. Thayer and J.J. Maurer. (2002): Distribution of Staphylococci enterotoxin genes among Staphylococcus aureus isolated from poultry and humans with invasive staphylococcal disease. Avian Diseases, 46 (1): 132-136.

Kanatt, R. Sweetie, Chander, R.\& Sharma,A.(2010): Antioxidant and antimicrobial activity of pomegranate peel extract improves the shelf life of chicken products.

Int. J. of Food Science and Technology. (45):216222.

Kantachote, D. and Charernjiratrakul, W. (2008): Selection of lactic acid bacteria from fermented plant beverages to use as inoculants for improving the quality of the finished product. Pakistan J. Biol. Sci., 1-8.

Manna AC. (2012): Synthesis, characterization, and antimicrobial activity of zinc oxide nanoparticles. In: Cioffi N, Rai M, editors. Nano-antimicrobials: progress and prospects. Berlin: Springer Press; p. 151180.

Mirhosseini, M. and Arjmand V. (2014): Reducing Pathogens by Using Zinc Oxide Nanoparticles and Acetic Acid in Sheep Meat. J. of Food Protection,77 (9):15991604.

Mottaki, R.A.; Baei, M.T.; and Moghimi, M. (2014): Influence of Zinc Oxide Nanoparticle ( $\mathrm{ZnO})$, Peppermint Extract and Their Combination on the Growth of Bacteria in Meat. Adv. Environ. Biol., 8(24): 230-234. 
Padmavathy, N., \& Vijayaraghavan, R. (2008): Enhanced bioactivity of $\mathrm{ZnO}$ nanoparticles - an antimicrobial study. Science and Technology of Advanced Materials, 9(3), 035004.

Peng, X., Palma, S., Fisher,N.S, Wong, S.S (2011):Effect of morphology of $\mathrm{ZnO}$ nanostructures on their toxicity to marine algae. Aquat. Toxicol., 102(3): 186-196.

Prescott, L.M.; Harely, J.P. and Klein, D. A. (2002): Microbiology. $5^{\text {th }}$ ed, McGraw Hill comp. USA.

Rai, M.; Yadav, A.; Gade, A. (2009): Silver nanoparticles as a new generation of antimicrobials. Biotechnol. Adv., 27(1):7683.

Ramani, M.; Ponnusamy, S.; Muthamizhchelvan, C.; Marsili, E. (2014): Amino acid-mediated synthesis of zinc oxide nanostructures and evaluation of their facet-dependent antimicrobial activity. Colloids Surf. B 117, 233-239.

Roselli M, Finamore A, Garaguso I, BrittiMS, Mengheri E (2003): Zinc oxide protects cultured enterocytes from the damage induced by Escherichia coli. J Nutr., 133(12):4077-4082.

Ren G, Hu D, Cheng EWC, Vargas-ReusMA, Reip P, Allaker RP (2009): Characterization of copper oxide nanoparticles for antimicrobial applications. Int. J. Antimicrob Agents, 33(6):587-590.

Roco, M. C. (1999): Towards a US national nanotechnology initiative. Journal of Nanoparticle Research, 1(4), 435-438.

Saeed, S. and Tariq, P. (2005): Antibacterial activities of Mentha piperita, Pisum sativum and Momordica charantia. Pak. J. Bot., 37(4): 997-1001.

Sawai, J. (2003): Quantitative evaluation of antibacterial activities of metallic oxide powders $(\mathrm{ZnO}, \mathrm{MgO}$ and $\mathrm{CaO})$ by conductimetric assay. J Microbiol Methods, 54(2):177-182.

Schirmer, B. C., Heiberg, R., Eie, T., Møretrø, T., Maugesten, T., Carlehøg, M., \& Langsrud, S. (2009): A novel packaging method with a dissolving $\mathrm{CO} 2$ headspace combined with organic acids prolongs the shelf life of fresh salmon. International Journal of Food Microbiology, 133(1-2): 154-160.

Sirelkhatim, A.; Mahmud, S.; Seeni,A.; Kaus, N.H.M; Ann, L.C.; Bakhori, S.K.M; Hasan, H.; and Mohamad, D. (2015): Review on zinc oxide nanoparticles: Antibacterial activity and toxicity mechanism. NanoMicro Lett., 7(3):219-242.

Stewart, C.M.; Cole, M.B. and Schaffner, D.W. (2003): Managing the risk of staphylococcal food poisoning from cream- filled baked goods to meet a food safety objective. J. Food Prot.,66: 1310-25.

Stoimenov, P. K., Klinger, R. L., Marchin, G. L., \& Klabunde, K. J. (2002): Metal oxide nanoparticles as bactericidal agents. Langmuir, 18(17): 6679-6686.

Zhang, L., Jiang, Y., Ding, Y., Povey, M., \& York, D. (2007): Investigation into the antibacterial behaviour of suspensions of $\mathrm{ZnO}$ nanoparticles ( $\mathrm{ZnO}$ nanofluids). Journal of Nanoparticle Research, 9(3): 479-489. 